\title{
NITROGEN AND PHOSPHORUS AS INDICATORS OF CHANGES IN THE DANUBE ECOSYSTEM IN SERBIA
}

Ivana Mladenović-Ranisavljević ${ }^{*}$, Ljiljana Takić ${ }^{1}$, Milovan Vuković2

\footnotetext{
${ }^{1}$ University of Niš, Faculty of Technology, Leskovac, Serbia

2University of Belgrade, Technical faculty, Bor, Serbia
}

The assessment of the Danube water pollution in this study was conducted based on the content of total nitrogen $(\mathrm{N})$ and total phosphorus $(\mathrm{P})$ in the water samples collected from three measuring stations on the Danube River in Serbia. The stations were selected with the intention to depict the three points of the flow of the river through Serbia, namely, the input, center and output profile of the river. The values of the indicators of nutrients were observed annually in the time period from 2013 to 2015 , as the average value of monthly measurements at each station, and compared with the limit values prescribed by the Regulations on limit values of pollutants in the surface and ground waters and sediments. In addition, the paper presents the three-year trend of changes in the value of the observed parameters in order to determine certain regularity of changes in the content of nitrogen and phosphorus in the water. Also, fluctuations in the value on a monthly basis are also taken into consideration and are presented in this paper in order to see all possible deviations and trend of changes per annum. The results obtained in this paper showed that nutrient concentrations have exceeded prescribed limit values which put the water quality of the Danube River into class III according to current regulations in Serbia, indicating the nutrient pollution of the Danube at the observed locations. The threeyear trend of changes points to the tendency of the linear growth of nutrients in the aquatic ecosystem of the Danube which are endangering the quality of water, and this is an alarm signal and urgent call for the implementation of appropriate protective measures.
(ORIGINAL SCIENTIFIC PAPER) UDC 502.51:546.17/.18(282.243.7)(497.11)

Keywords: water pollution, total N, total $\mathrm{P}$, the Danube ecosystem.

\section{Introduction}

The Danube is the $2.888 \mathrm{~km}$ long international river, with the basin covering $816.947 \mathrm{~km}^{2}$ of the surface area, which represents $8.5 \%$ of the surface of Europe. There are ten different nations living alongside the Danube River and about 80 million Europeans in its basin. About ten percent of the total area of the Danube River basin belongs to Serbia, while the length of the flow is $588 \mathrm{~km}$.

Often caused by human factor, the Danube water today accumulates raw sewage from cities, agricultural chemicals, waste from factories, oil slicks and products of combustion drive motor boats. Part of this pollution eventually settles on the banks of the river and disrupts the natural balance of the ecosystem with serious consequences for flora, fauna and the habitants [1, 2, 3, 8, 9]. So far, testing of the water quality of the Danube River covered by the Plan for the Danube River Basin Management [4] identified four major problems related to the water quality (concerning the surface and groundwater, both chemical and ecological status) across the Danube Basin: organic pollution, nutrient pollution, contamination as a result of dangerous substances and hydro-morphological changes of rivers. Nutrient pollution of water is usually caused by erosion and rinsing of arable land as a result of the use of artificial, mineral fertilizers in the soil processing, or as a result of livestock or manure by the water. The concentration of nutrients in water is influenced by various household or industrial detergents, excess herbicides, insecticides, oils, fats and numerous toxic chemicals from the urban environment, as well as precipitation of salt during irrigation, acid from abandoned mines or sediments from the site, crops and forest land [5].

Natural water and wastewater contain phosphorus in various phosphate forms such as orthophosphate, condensed phosphates and organic phosphorus combined. They are present in the solution, humus particles or aquatic organisms. Usually, the content of phosphate in natural water is not high, unlike industrial wastewater and domestic sewage like fertilizer, smelting and synthetic detergent industries. A high content of phosphorus in water can cause algae overgrowth, the occurrence known as eutrophication, resulting in the increased turbidity of water and water quality disruption. The discharge of the industrial wastewater containing nitrogen into water bodies, along with domestic sewage or agricultural drainage, mostly cause the organic

\footnotetext{
* Author address: Ivana Mladenović Ranisavljević, Faculty of Technology, 16000 Leskovac, Bulevar oslobodjenja 124, Serbia

E-mail: 282ivana@gmail.com

The manuscript received: July, 20, 2017.

Paper accepted: September, 16, 2017
} 
nitrogen and various inorganic nitrogen compounds to increase and breed a large number of micro-organisms that reduce a great deal of dissolved oxygen in water and deteriorate the water quality. When there are excessive nitrogen and phosphorus substances in water bodies, then serious phytoplankton reproduction and eutrophication of aquatic ecosystems occur. Therefore, phosphorus and nitrogen are important indicators of the water quality evaluation.

The aim of this paper is to point out the part of the Danube in Serbia (input, central or output profile) which is critical in relation to the content of nutrients observed, and to indicate the future trend of changes in the ecosystem of the Danube in Serbia.

\section{Experimental}

\section{Materials and Method}

The study of the water pollution of the Danube includes three measuring stations chosen to present the input, output and the central part of the river flow in Serbia at a certain distance from the river mouth:

1. Bezdan - input profile $(1425.59 \mathrm{~km})$,

2. Zemun - central profile $(1174 \mathrm{~km})$ and

3. Radujevac - output profile (852 km).

The analysis included two indicators of the nutrient content in the water, total nitrogen $(\mathrm{N})$ and total phosphorous $(\mathrm{P})$, determined according to accredited methods. Total $\mathrm{N}$ was examined according to DIN EN ISO 11905-2, while total $P$ was determined according to APHA AWWA WEF 4500-P (A, B, E) method.

The official Republic monitoring data on the water quality for the time period from 2013 to 2015 were used as a starting point in the current research. Parameters are monitored on a monthly basis by the Republic Hydro Meteorological Service of Serbia (RHMS), and presented to the public in a form of a survey [6]. During the time period from January to December 2013, 12 measurements per annum were carried out at the Bezdan location for total $\mathrm{P}$ and 11 for total $\mathrm{N}$, while at the other two locations only 11 measurements per annum for both of the parameters were conducted.

The comparison with the limit values of pollutants in surface waters prescribed by the national Regulation [7] was used to determine elevated concentrations of nutrients in water, along with the class of the water quality at the observed locations.

\section{Results and Discussion}

The average annual values of selected parameters in 2013 at the observed locations were calculated and presented in Table 1 together with the limit values according to national legislation.
Table 1. Calculated and prescribed limit values at the observed locations in 2013

\begin{tabular}{llcc}
\hline Locations & Unit & Total N & Total P \\
\hline Bezdan & $\mathrm{mg} / \mathrm{l}$ & 2.32 & 0.19 \\
Zemun & $\mathrm{mg} / \mathrm{l}$ & 2.13 & 0.09 \\
Radujevac & $\mathrm{mg} / \mathrm{l}$ & 1.92 & 0.11 \\
Limit values & & & \\
I class & $\mathrm{mg} / \mathrm{l}$ & 1 & 0.05 \\
II class & $\mathrm{mg} / \mathrm{l}$ & 2 & 0.05 \\
III class & $\mathrm{mg} / \mathrm{l}$ & 8 & 0.4 \\
IV class & $\mathrm{mg} / \mathrm{l}$ & 15 & 1 \\
V class & $\mathrm{mg} / \mathrm{l}$ & $>15$ & $>1$ \\
\hline
\end{tabular}

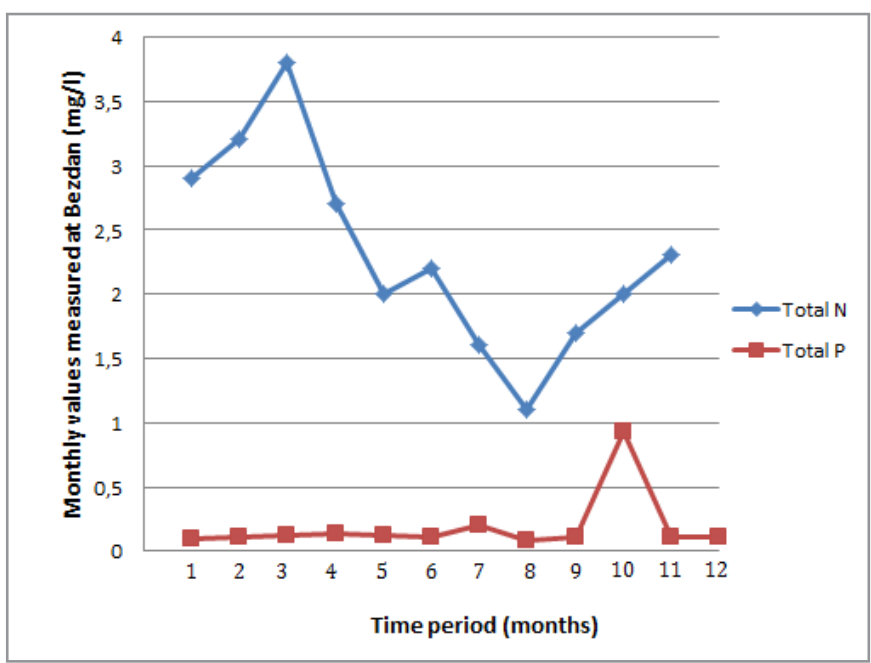

Figure 1. Variation of total $\mathrm{N}$ and total $\mathrm{P}$ values on a monthly basis at the Bezdan location

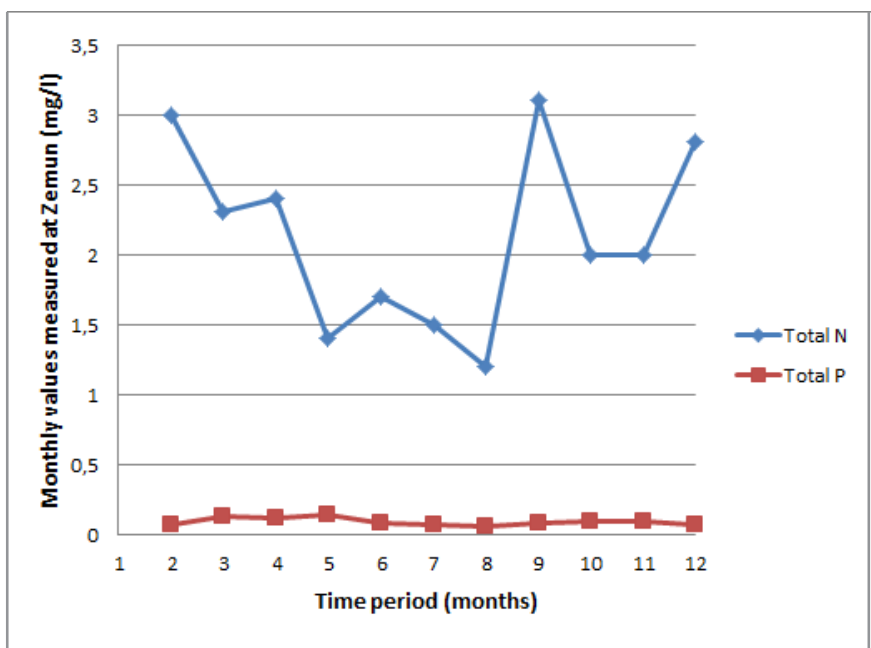

Figure 2. Variation of total $\mathrm{N}$ and total $\mathrm{P}$ values on a monthly basis at the Zemun location 


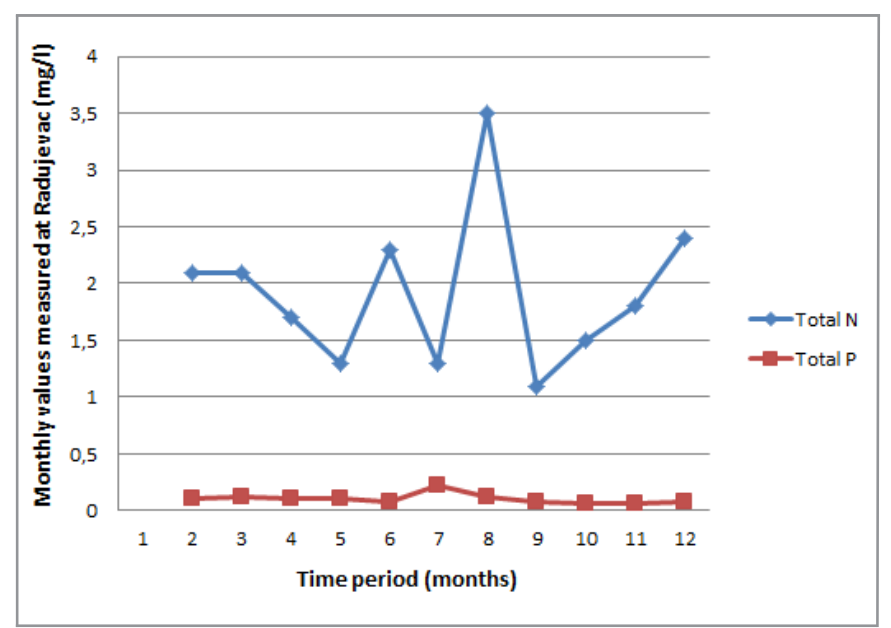

Figure 3. Variation of total $\mathrm{N}$ and total $\mathrm{P}$ values on a monthly basis at the Radujevac location

Graphical presentation of the variation of the nutrient content during the year, on a monthly basis, is shown individually for the Bezdan location (Figure 1), Zemun (Figure 2) and the Radujevac location (Figure 3) and discussed afterwards. There is an evident peak in monthly values of total $P$ recorded in October at Bezdan (Figure 1), where the increased value reached $0.930 \mathrm{mg} / \mathrm{l}$, which is probably the consequence of massive floods along the Danube River recorded earlier in the year that led to erosion and rinsing of arable land.

Based on the calculated average value of the total $\mathrm{N}$ content and in comparison with the prescribed limit values (Table 1), it can be concluded that the content of this nutrient indicator corresponds to Class II $(1.92 \mathrm{mg} / \mathrm{l})$ at the Radujevac location and class III of the water quality at both Bezdan $(2.32 \mathrm{mg} / \mathrm{l})$ and Zemun $(2.13 \mathrm{mg} / \mathrm{l})$ locations. However, by observing the variation of this indicator on a monthly basis (Figure 3 ) the water quality at this location is generally classified into the worse class (i.e. class III), due to individual monthly values, which in several measurements significantly exceed the prescribed limit value of $2 \mathrm{mg} / \mathrm{I}$.

The calculated average values of the total $P$ at all measuring locations $(0.19 \mathrm{mg} / \mathrm{l}, 0.09 \mathrm{mg} / \mathrm{l}$ and $0.11 \mathrm{mg} / \mathrm{l}$, respectively) are in accordance with monthly oscillations of these indicators and together classify the Danube water quality into the class III, according to Regulations.

The regularity of changes in the Danube ecosystem over the time period from 2013 to 2015 was obtained in Table 2 by analyzing the average annual values of the observed parameters at each location, as well as the summarized average values for each year.

Average annual values were calculated for each year and the variations of empirical series are expressed graphically in a trend line that shows the average trend of changes in total $\mathrm{N}$ (Figure 4) and total P (Figure 5) for a three-year period of time. Figure 4. gives the empirical series of total $\mathrm{N}$ values and a linear fit with the average quality trend of -78.48 and the absolute growth of average $0.04 \mathrm{mg} / \mathrm{l}$ of total $\mathrm{N}$ in the water during the analyzed period. Empirical series of total $\mathrm{P}$ values presented in Figure 5 show a linear fit with the average quality trend of -20.01 and the absolute growth of average $0.01 \mathrm{mg} / \mathrm{l}$ of total $\mathrm{P}$ in the water in the observed three-year period

Table 2. Values of total $\mathrm{N}$ and total $\mathrm{P}$ over the three-year period of time

\begin{tabular}{llcccccc}
\hline & & $\mathbf{2 0 1 3}$ & \multicolumn{3}{c}{$\mathbf{2 0 1 4}$} & $\mathbf{2 0 1 5}$ \\
\hline Locations & Unit & Total N & Total P & Total N & Total P & Total N & Total P \\
Bezdan & $\mathrm{mg} / \mathrm{I}$ & 2.32 & 0.19 & 2.17 & 0.12 & 2.49 & 0.10 \\
Zemun & $\mathrm{mg} / \mathrm{I}$ & 2.13 & 0.09 & 1.93 & 0.10 & 2.13 & 0.09 \\
Radujevac & $\mathrm{mg} / \mathrm{I}$ & 1.92 & 0.11 & 1.68 & 0.17 & 1.97 & 0.27 \\
Avg. value & $\mathrm{mg} / \mathrm{I}$ & 2.12 & 0.13 & 1.93 & 0.13 & 2.20 & 0.15 \\
\hline
\end{tabular}

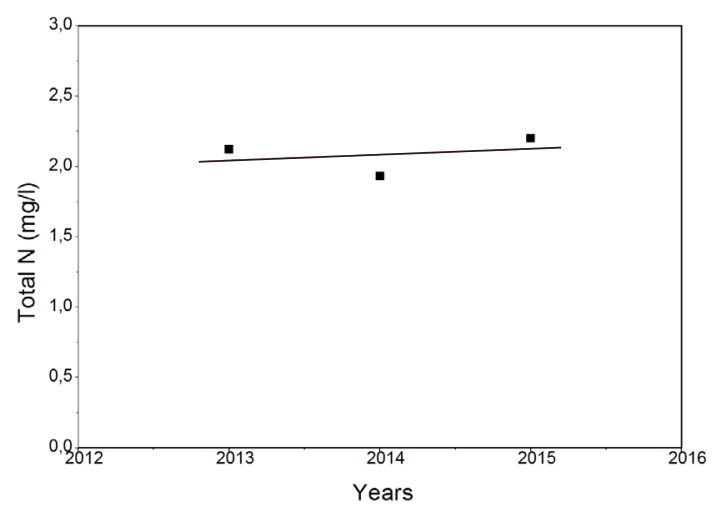

Figure 4. Trend of changes in total $\mathrm{N}$

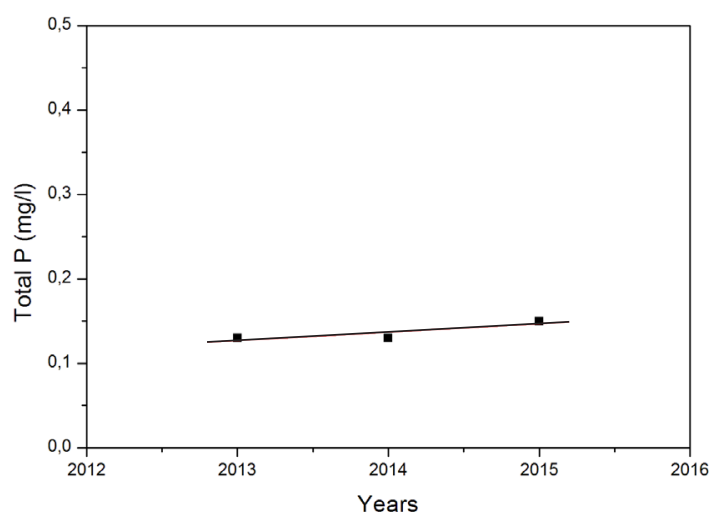

Figure 5. Trend of changes in total $P$ 
The analysis of two water pollution indicators confirms the previous analyzes conducted by the authors on the Danube $[8,9,10,11]$ and shows that the Danube water quality in Serbia is with increased concentrations of nutrient indicators (total $\mathrm{P}$ and total $\mathrm{N}$ ), with a linear trend of growth, so it is necessary to implement appropriate measures in order to reduce the sources of pollution and to protect the Danube ecosystem fundamentally from further pollution.

\section{Conclusion}

The results obtained in the paper show that the less polluted water quality is obtained at the output profile of the river flow (Radujevac measuring station) than on the other two parts of the river flow. More specifically, calculated values of total $\mathrm{N}$ in 2013 at Bezdan, Zemun and Radujevac were $2.32 \mathrm{mg} / \mathrm{l}, 2.13 \mathrm{mg} / \mathrm{l}$ and $1.92 \mathrm{mg} / \mathrm{l}$, while the values of total $P$ were $0.19 \mathrm{mg} / \mathrm{l}, 0.090 \mathrm{mg} / \mathrm{l}$ and $0.11 \mathrm{mg} / \mathrm{l}$, respectively. Fluctuations in the value on a monthly basis defined the water pollution at selected measuring stations more closely and, according to current regulations in Serbia, ranked the water quality of the Danube into class III. The Danube water quality determined by a median of arranged series of both total $\mathrm{N}$ and total $P$ average values over a three-year period of time at the observed measuring points in Serbia indicates the nutrient pollution growth. Linear trend of growth of both nitrogen and phosphorus content clearly indicates negative and adverse changes in the quality of the Danube ecosystem in Serbia. It was therefore concluded that adequate measures need to be implemented at the observed locations to reduce the nutrient pollution of the Danube ecosystem and to improve the overall quality of this valuable water resource which is decreasing over the years.

\section{Acknowledgements}

This work is a part of the research done within the project no. TR34012 funded by the Serbian Ministry of Education, Science and Technological Development.

\section{References}

[1] L. Somlyódy, P.H. Brunnerand, H. Kroiss, Nutrient balances for Danube countries: A strategic analysis, Water Science and Technology, 40 (10) (1999) 9-16.

[2] I. Navodaru, M. Staras, I. Cernisencu, The challenge of sustainable use of the Danube Delta Fisheries, Romania, Fisheries Management and Ecology, (8) (4-5) (2001) (323-332).

[3] I. Jarić, Ž. Višnjić-Jeftić, G. Cvijanović, Z. Gačić, Lj. Jovanović, S. Skorić, M. Lenhardt, Determination of differential heavy metal and trace element accumulation in liver, gills, intestine and muscle of sterlet (Acipenser ruthenus) from the Danube River in Serbia by ICP-OES, Microchemical Journal, 98 (1) (2011) 77-81.

[4] Action Strategy Plan of European Union for the Danube
Region, European Commission, Brisel, SEC (2010) 1489/3. Available at: http://www.dunavskastrategija.rs (Accessed 10 January 2015)

[5] N. Veljković, M. Jovičić, Analiza trenda koncentracija nutrijenata u vodotocima Srbije, Collection of papers, Water 2012, SDZV and Institute J. Černi , Divčibare, 2012, p. 69-74 (in Serbian).

[6] Ministry of Agriculture and Environmental Protection, Agency for Environmental Protection of the Republic of Serbia, Annual Report: The results of testing the quality of surface and groundwater in 2013, Belgrade 2014.

[7] Regulation on limit values of pollutants in surface and ground waters and sediments, with deadlines for their achievement (Official Gazette of the RS, No. 50/2012).

[8] D. Voza, M. Vuković, Lj. Takić, Đ. Nikolić, I. MladenovićRanisavljević, Application of multivariate statistical techniques in the water quality assessment of Danube river, Serbia. Archives of Environmental Protection 41 (4) (2015) 96-103.

[9] Lj. Takić, I. Mladenović-Ranisavljević, M. Vuković, I. Mladenović, Evaluation of the Ecochemical Status of the Danube in Serbia in Terms of Water Quality Parameters, The Scientific World Journal (2012), Article ID 930737, 6 pages. doi:10.1100/2012/930737.

[10] I. Mladenović-Ranisavljević, Lj. Takić, M. Vuković, Đ. Nikolić, N. Živković, P. Milosavljević, Multi-criteria ranking of the Danube water quality on its course through Serbia, Serbian Journal of Management, 7 (2) (2012) 299-307.

[11] I. Mladenović-Ranisavljević, Lj. Takić, V. Nikolić, Lj. Nikolić, D. Stoiljković, P. Ranisavljević, Procena zagađenosti vode Dunava primenom višekriterijumske analize, Savremene tehnologije, 2 (2) (2013), 59-63. 


\section{AZOT I FOSFOR KAO INDIKATORI PROMENA U EKOSISTEMU DUNAV U SRBIJI}

Ivana Mladenović-Ranisavljević1 ${ }^{1}$ Ljiljana Takić1, Milovan Vuković2

\footnotetext{
${ }^{1}$ Univerzitet u Nišu, Tehnološki fakultet, Leskovac, Srbija
}

2Univerzitet u Beogradu, Tehnički fakultet, Bor, Srbija

Procena zagađenja vode Dunava u ovoj studiji sprovedena je na osnovu sadržaja ukupnog azota $(\mathrm{N})$ i ukupnog fosfora $(\mathrm{P})$ u uzorcima prikupljenim sa tri merne stanice na Dunavu u Srbiji. Stanice su odabrane sa namerom da se prikažu tri tačke toka reke kroz Srbiju, odnosno ulazni, središnji i izlazni deo toka reke. Vrednosti indikatora nutrijenata posmatrane su kao prosečne godišnje vrednosti na svakoj stanici, u periodu od 2013. do 2015. godine i upoređene su sa graničnim vrednostima propisanim Pravilnikom o graničnim vrednostima zagađivača u površinskim i podzemnim vodama i sedimentima. Pored toga, u radu je prikazan i trogodišnji trend promena vrednosti posmatranih parametara kako bi se utvrdila izvesna zakonitost $u$ promenama sadržaja azota i fosfora u vodi. Takođe, uzete su u obzir i fluktuacije vrednosti na mesečnom nivou i predstavljene su u ovom radu kako bi se uočila sva moguća odstupanja i trendovi promena u toku jedne godine. Rezultati dobijeni u radu pokazuju da su koncentracije nutrijenata premašile propisane granične vrednosti, što kvalitet vode reke Dunav svrstava u klasu III (prema važećim propisima u Srbiji) i ukazuje na zagađenje Dunava nutrijentima na posmatranim lokacijama. Trogodišnji trend promena ukazuje na tenden-ciju linearnog rasta sadržaja nutrijenata u vodi ekosistema Dunav, i, posledično, ugrožavanje kvaliteta vode, što je znak za uzbunu i poziv na urgentno implementiranje odgovarajućih zaštitnih mera.
(ORIGINALNI NAUČNI RAD)

UDK 502.51:546.17/.18(282.243.7)(497.11)

Ključne reči: zagađenje vode, ukupni azot, ukupni fosfor, ekosistem Dunava. 